\title{
Bogtrykkerne i København
}

af fhv. overbibliotekar Torben Nielsen:

\section{Omtale af}

Harald Ilsøe: Bogtrykkerne i København og deres virksomhed ca. 1600-1810. En biobibliografisk håndbog med bidrag til bogproduktionens historie. Det kongelige Bibliotek, Museum Tusculanums Forlag, København 1992. 304 s., ill. (Danish humanist texts and studies, 5.) Kr. 298,-

Boghistorie er et fag med mange aspekter. Skal vi skematisere, finder vi på den ene side bogen som teknisk-æstetisk produkt: Hvordan er den fremstillet, og hvor vellykket er den blevet? - og på den anden side bogen som kommunikationsfaktor, betinget af sociale og økonomiske vilkår og krav.

Det tør vel siges, at det er den første af disse kategorier, der i tidens løb har været dominerende og derfor i nogen grad har "tegnet" boghistorien i den almindelige bevidsthed som en gren af kunst- og stilhistorien. Vist er det mere tilfredsstillende at have en smuk bog $i$ hånden end et sjusket klamphuggerprodukt, men drejer det sig om at måle udbredelsen af nyheder og kundskaber, vejer deæstetiske kvaliteter mindre til; blandt de slette tryk findes massevarer, der ved deres udbredelse bidrager til at tegne en tidsalders eller et miljøs profil. Til denne, lad os med et rundt ord kalde den litteratursociologiske, forskningsgren hører også spørgsmålet om bogproduktionens materielle vilkår. Således betragtet er det ikke blot bogtrykkerkunstens toppræstationer, der interesserer os; for alle bogproducenter - eller man burde vel hellere sige: producenter af tryksager - er spørgsmålet relevant: Hvad producerede de, hvad havde deaf værkstedsudstyr og materiel? Og hvordan hang detøkonomisk sammen?

For Danmarks vedkommende er vi vel hjulpne indtil slutningen af det 16. århundrede; der har vi Lauritz Nielsens Danske Bibliografi, der beskriver samtlige tryk uanset betydning efter inkunabelforskningens mønster. Med 


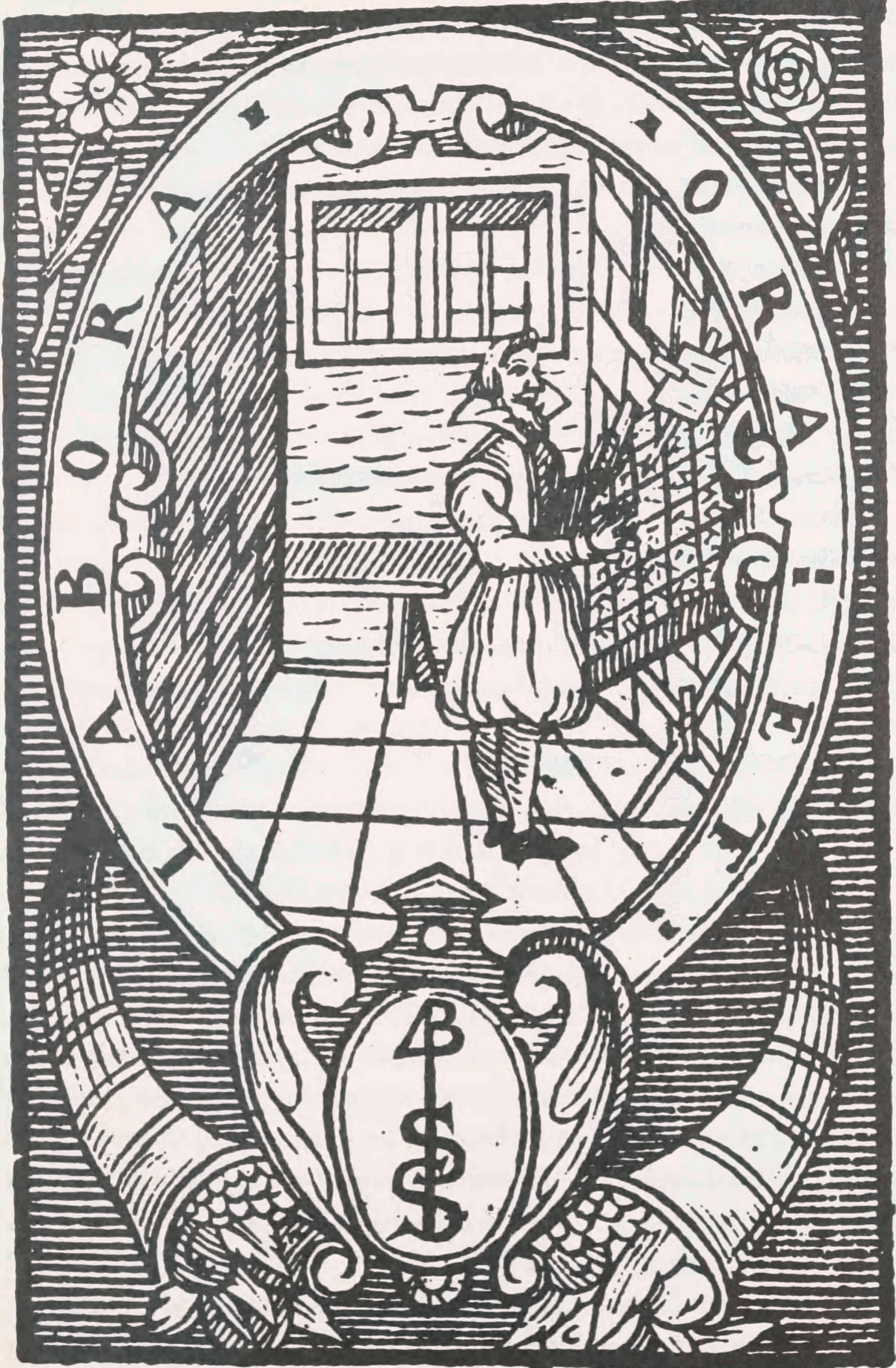

Salomon Sartors bogtrykkermærke med den ældste danske afbildning af en sætter ved sættekassen, 1621. 
den stigende produktion ville det naturligvis være utænkeligt at fortsætte i samme spor, men fra 1601 har vi langt hen været henvist til de summarisk affattede titler i Bibliotheca Danica. Her bør det dog indskydes, at der ved Erik Dals initiativ og med ham selv som aktiv medarbejder er gennemført grundige registreringer af dansk provinstryk før 1830; noget trykt, noget utrykt, andet endnu under udarbejdelse. Undersøgelserne viser, at der i den centraliserede stat fandtes mindre centre af lokal og regional betydning. Men selvom den samlede provinsbibliografi kommer til at omfatte 5 bind, er det alligevel overskueligt i sammenligning med monarkiets hovedstads produktion. Den må gribes anderledes an, og det er, hvad Harald Ilsøe har taget sig på i sin nye bog; med mistanke for at levere bestilt forlagsreklame tøver jeg dog ikke med at kalde den et forblivende standardværk i dansk kulturhistorie.

Kærnen i Ilsøes værk er de 103 kapitler om de bogtrykkere, der spænder over de 210 år, som titlen angiver. For hver af dem meddeles en biografi, der naturligvis koncentreres om hans/hendes professionelle virksomhed; denne karakteriseres $i$ henseende til arten af produktion, trykkeriets tekniske udrustning og personale, bogtrykkerens økonomiskeforhold og positive eller negative berøringer med øvrigheden. Der er gode bogtrykkere og deriblandt nogle, som man uden at ryste på hånden kan kalde kunstnere i deres fag, som Godiche og Nic. Møller, for blot at nævne et par stykker, og der er klodsmajorer som Brandt og Phønixberg. Der er enkelte, der skabte sig en formue, men flere, der ikke gjorde det. Der er sørgmodig-drastiske episoder, som da Schmedtgens trykmateriale faldt overbord fra generalskibet Elefanten i 1710, og da Glasing døde i 1752, fordi han var blevet forkølet ved at stå vagt med borgervæbningen ved dronning Louises begravelse.Vi læser om stort anlagte foretagender, f.ex. Pontoppidans Danske Atlas, som Godicheovertog og videreførte for egen regning, men også om småfiduser, som selv agtede bogtrykkere kunne gribe til; når f.ex. Seidelin udgiver et skrift med titlen „Det syndige i Kjønsdriftens uordentlige Tilfredsstillelse" - der i virkeligheden er en prædiken af Claus Pavels - minder det om de udgaver, man har set af Kierkegaards „Forførerens Dagbog" udstyret med „husaromslag".

I tilslutning til disse fortællende afsnit gør Ilsøe nøje rede for kilder og anvendt litteratur. Det væsentlige spørgsmål: hvad den enkelte bogtrykker har trykt, løser Ilsøe på en enkel og effektiv måde, der afslører en overordentlig forskerflid: Han har gennemgåeten rækkebibliografiskeog andre boghistoriske 
værker og derfra noteret sig alle de titler, der kan henføres til et bestemt officin; som særligt givende, men også arbejdskrævende, nævner han i sit forord Hjalmar Pettersens Bibliotheca Norvegicas 10.000 titler. Han henviser da til de benyttede værker med sidehenvisninger og anfører, fra hvilket tidsrum de pågældende tryk stammer, og siger dermed til den, der måtte være interesseret i et enkelt trykkeris produktion: Værsåartig, der er serveret. Endelig nævner han naturligvis de tilfælde, hvor der fra bogtrykkerens egen hånd foreligger trykte lister over produktionen.

I et stort afsluttende kapitel samles de mange enkeltoplysninger til en afrundet fremstilling af den danske bogproduktion i den behandlede periode, med perspektivrig udnyttelse af statistiske data; her argumenterer han bl.a. overbevisende for, at oplagene i mange tilfælde har været større end hidtil antaget.

Når denne righoldige bog i korthed skal præsenteres, kan der naturligvis kun blive tale om lidt spredt fægtning, men forhåbentlig nok til at stimulere appetitten; den vil være uundværlig for generationer af boghistorikere, og for historisk-topografisk interesserede er den, som man kan tænke sig, fuld af københavnsk stof.

Det er morsomt, at man blandt de fonde, der har støttet trykningen, finder den Hielmstierne-RosencroneskeStiftelse; katalogen over Hielmstiernes bogsamling var et væsentligt arbejdsredskab for Ilsøes forgænger som bogtrykhistoriker: Rasmus Nyerup. Også andre har ydet støtte og derved erkendt værkets betydning: Alfred Goods personalhistoriske Fond, Konsul George Jorck og Hustru Emma Jorcks Fond, Statens humanistiske Forskningsråd og Landsdommer V. Gieses Legat. Sidstnævnte har finansieret værkets udstyrelse med illustrationer, prøver af tryk, især ornamenter, velvalgte eksempler på bogtrykkeres og formskæreres gennemsnitlige formåen.

Med udgivelsen af Harald Ilsøes bog har Det kongelige Bibliotek atter manifesteret sig som et centrum for boghistorisk forskning. Det er bl.a. sådant, man har et nationalbibliotek til. 